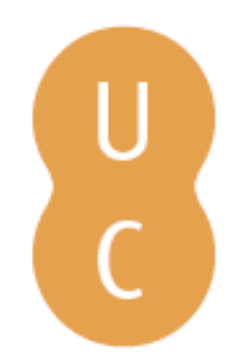

\title{
nommalina
}

\section{Republicanismo: considerações dos exilados acerca da República Portuguesa}

Autor(es): Paulo, Heloisa

Publicado por: Imprensa da Universidade de Coimbra

URL persistente:

URI:http://hdl.handle.net/10316.2/31144

DOI:

DOI:http://dx.doi.org/10.14195/978-989-26-0497-8_14

Accessed : $\quad$ 26-Apr-2023 05:59:38

A navegação consulta e descarregamento dos títulos inseridos nas Bibliotecas Digitais UC Digitalis, UC Pombalina e UC Impactum, pressupõem a aceitação plena e sem reservas dos Termos e Condições de Uso destas Bibliotecas Digitais, disponíveis em https://digitalis.uc.pt/pt-pt/termos.

Conforme exposto nos referidos Termos e Condições de Uso, o descarregamento de títulos de acesso restrito requer uma licença válida de autorização devendo o utilizador aceder ao(s) documento(s) a partir de um endereço de IP da instituição detentora da supramencionada licença.

Ao utilizador é apenas permitido o descarregamento para uso pessoal, pelo que o emprego do(s) título(s) descarregado(s) para outro fim, designadamente comercial, carece de autorização do respetivo autor ou editor da obra.

Na medida em que todas as obras da UC Digitalis se encontram protegidas pelo Código do Direito de Autor e Direitos Conexos e demais legislação aplicável, toda a cópia, parcial ou total, deste documento, nos casos em que é legalmente admitida, deverá conter ou fazer-se acompanhar por este aviso. 
Armando Malheiro da Silva

Maria Luiza Tucci Carneiro

Stefano Salmi

Coordenação

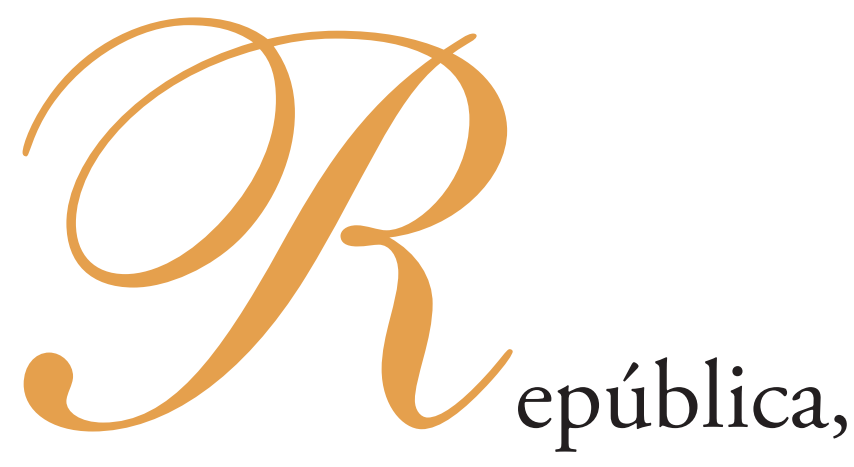

Republicanismo

e Republicanos

Brasil • Portugal • Itália 


\author{
Heloisa Paulo
}

\title{
REPUBLICANISMO: CONSIDERAÇÕES DOS EXILADOS ACERCA DA REPÚBLICA PORTUGUESA
}

O Republicanismo português: as contradições entre ideal e prática.

"Em 1910, abolia-se enfim a realeza. Fez-se então a verdadeira República? Não se fez.[...] Não passava de formalismo político (de simples negação, por assim dizer, da monarquia e do clericalismo) sem conteúdo concreto reformador na economia e na educação. Nem se aperfeiçoou a economia existente, nem se democratizou realmente nada; nenbum dos factores de importância [básica] na vida económica e moral (como a propriedade, o crédito, a educação [ou a assistência]) sofreu reformas que se faziam mister segundo o espirito da democracia, nem se abriram campos de actividade útil ao trabalho agrícola; aproveitamento da água dos rios na rega dos campos e na energia eléctrica; democratização do sistema creditário; fomento e protecção das instituições económicas populares, etc.), - reformas que favorecessem, enfim, a passagem do oligarquismo e comunitarismo de Estado a um regime progressivo de que beneficiasse o povo."

Sérgio, António, Obras Completas. Breve Interpretação da História dePortugal. Lisboa: Livraria Sá da Costa Editora. Lisboa, $10^{a}$ ed. 1981, P. 
O ataque de António Sérgio à República ${ }^{460}$ reflecte as contradições existentes entre os seus partidários, a sua ideologia e a sua prática política. Ainda que não esteja presente na visão de muitos republicanos, a consciência do distanciamento entre a sua prática discursiva e a realidade ao seu alcance é um facto que desperta a atenção dos mais experimentados e radicais nomes da República e daqueles para quem a vitória do 28 de Maio vai levar a um reexame dos antigos posicionamentos políticos.

$\mathrm{Na}$ verdade, o sistema republicano herda dos últimos anos da monarquia alguns dos problemas oriundos do estreito universo político da sociedade portuguesa, dominada pelas tradições do caciquismo, no interior, e pelo facto de a defesa dos ideais republicanos se limitar aos grandes centros urbanos ${ }^{461}$.

A imagem do "político" enquanto "homem público", criada a partir dos últimos anos de monarquia, continua a ser vista como motivo de desconfiança e crítica pelos defensores mais radicais do republicanismo. A condenação resulta do próprio sistema parlamentar, colocando em xeque muita da actuação dos seus membros. Concomitantemente, o distanciamento entre o discurso político e a sua prática, exemplificado no problema da universalidade do voto, contribui para o fraco alcance dos ideais republicanos ${ }^{462}$.

Assim sendo, desde Manuel de Arriaga até àqueles que combatem no exílio, após 1926, verificamos uma "autocrítica" que condena os factores que justificam o clima de "instabilidade" da Primeira República463. A rejeição da imagem do "político profissional" e o reconhecimento das "falhas" do sistema representativo, longe de espelharem a incoerência de limitar o discurso ao reconhecimento das escassas bases de apoio político, servem de argumento para verdadeiros "exames de consciência" por parte dos mais intransigentes:

\footnotetext{
${ }^{460}$ Sobre a contradição a respeito do republicanismo de António Sérgio ver, entre outros, MARQUES, A.H. de Oliveira - "Sérgio no Exílio (1927-1928)". In Ensaios de História da República Portuguesa. Lisboa: Livros Horizonte, 1988,. pp. 283 e seguintes.

${ }^{461}$ Sobre o tema, ver, entre outros, LOPES, F. Farelo - Poder Político e Caciquismo na I. ${ }^{a}$ República Portuguesa. Lisboa: Estampa, 1994.

${ }^{462}$ Sobre o tema, ver, entre outros, CATROGA, Fernando - O Republicanismo em Portugal da formação ao 5 de Outubro de 1910. Lisboa: Notícias Editorial, 2000; VALENTE, Vasco Pulido - A "República Velha” (1910-1917). Lisboa: Gradiva. 1997;

${ }^{463}$ Apesar da "autocrítica", no caso do voto universal, alguns autores apontam a falta de ressonância que tal questão tem entre a sociedade, ver, entre outros, LOPES, F. Farelo. op. cit.; PINTO, António Costa - "A queda da I. ${ }^{a}$ República Portuguesa. Uma interpretação". In BAIÔA, Manuel (ed.) - Elites e Poder. A crise do Sistema Liberal em Portugal e Espanha. (1918-1931). Lisboa: Colibri/CIDEHUS, 2004, pp. 163-183.
} 
"Começaremos por confessar que nunca fomos politicos de profissão. A política tal como ela se pratica em Portugal, deturpando a pureza do sufrágio, foi sempre aos nossos olhos uma das causas primaciais da degradação dos costumes e da decadência do País"464.

A visão do político como um "mobilizador das massas" é sobreposta à do "servidor" da causa política (ou pública?), defensor dos ideais republicanos pelos quais combate e permanece fiel até no exílio ${ }^{465}$ :

"Não era por modéstia ou por manha que me queixava das minhas mediocres qualidades de político. Uma reflexão sobre o meu passado (e quanto ele já é escandalosamente longo) mostrava-me a realidade palpável. Sabia manter-se numa posição, quando nela havia uma missão a desempenhar e nela estava investido com legitimidade, e nela quase mesmo que era um tanto duro de roer. Porém, conquistar posições, arrebanhar adeptos, criar admiradores, foi sempre para mim uma tarefa profundamente desagradável e raras vezes a tentei" [... ${ }^{466}$.

As dissidências internas no movimento republicano apontam para a diversidade de leituras que os seus postulados oferecem aos seus seguidores. As arestas aparadas na elaboração do texto constitucional apontam para as principais divergências entre os futuros partidos, como as relativas à questão do federalismo ${ }^{467}$, sem contudo abandonar algumas das temáticas comuns a todos os republicanos, nomeadamente as questões da necessidade de um Estado Laico e da prioridade da Educação como arma para a formação da cidadania ${ }^{468}$. Os principais problemas

${ }^{464}$ ARRIAGA, Manuel de - Na primeira Presidência da República Portuguesa. Um rápido relatório. Lisboa: Livraria Clássica Editora, 1916, p. 9.

465 Sobre o tema, ver, entre outros, REIS, António - "Os valores republicanos de ontem e hoje". In Idem (org.) A República Ontem e Hoje. Lisboa: Ed. Colibri/Fundação Mário Soares/Instituto de História Contemporânea da Faculdade de Ciências Sociais e Humanas da Universidade Nova de Lisboa, 2002, pp. 11-29.

${ }^{466}$ Carta de Jaime de Morais a Moura Pinto e Jaime Cortesão. Sem data, Arquivo Jaime de Morais, Fundação Mário Soares.

${ }^{467}$ Sobre o tema, ver, entre outros, LEAL, Ernesto Castro - "A ideia federal no Republicanismo Português (1910-1926)”. In Revista de História das Ideias, Coimbra, vol. 27 (2006), pp. 251-291.

${ }^{468}$ Sobre o tema ver, entre outros, CATROGA, Fernando - op. cit.; FARINHA, Luís - "O Parlamento Republicano, funcionamento e reformas (1918-1926). In BAIÔA, Manuel.(ed), op. cit., pp. 47-77; HOMEM, Amadeu Carvalho - A propaganda republicana 1870-1910. Coimbra: Ediliber, 1990. 
de organização do Estado reaparecem nos momentos de maior crise, como foi a questão do presidencialismo com Sidónio Pais ${ }^{469}$.

As contradições são ainda maiores no que respeita ao próprio funcionamento do sistema parlamentar. A crescente predominância do Partido Democrático não impede que surjam vozes "dissonantes". O aparecimento da Esquerda Democrática abre espaço para um discurso mais radical, mas a estruturação do sistema impede o consenso na resolução dos problemas sociais e políticos do primeiro período republicano ${ }^{470}$.

Seguindo este tipo de análise, a historiografia acentua as dissidências internas da República e a falta de um plano geral de actuação que, ao mesmo tempo, favorecesse a expansão dos ideais republicanos para além dos círculos urbanos e conciliasse os interesses dos seus elementos mais radicais com as propostas dos grupos conservadores ${ }^{471}$. O retrato de uma República instável, marcada pela repressão e pelo radicalismo, é uma constante na visão dos defensores e na dos opositores ao regime ${ }^{472}$.

Em 1926, quando a implantação da ditadura militar marcar o fim da Primeira República e forçar os republicanos ao exílio, os antigos erros serão assumidos como possíveis "caminhos" na descoberta de saídas que conduzam o País à normalidade democrática.

${ }^{469}$ Sobre o tema ver, entre outros, SILVA, Armando M. - Sidónio e Sidonismo, História de uma vida. V. 1. Coimbra: Imprensa da Universidade de Coimbra, 2006.

${ }^{470}$ Sobre o tema, ver, entre outros, FARINHA, Luís - "O Parlamento Republicano, funcionamento e reformas (1918-1926). In BAIÔA, Manuel (ed) - op. cit.; TENGARRINHA, José - "Os Republicanos na resistência a ditadura militar e ao Estado Novo". In REIS, António (org.) - A República Ontem e Hoje, Lisboa: Ed. Colibri/Fundação Mário Soares/Instituto de História Contemporânea da Faculdade de Ciências Sociais e Humanas da Universidade Nova de Lisboa, 2002.

${ }^{471}$ Podemos encontrar tais considerações em diversas obras, desde clássicos, como nas obras de Oliveira Marques e outros autores (por exemplo, MARQUES, A. H. Oliveira - A I. ${ }^{a}$ República Portuguesa. Lisboa: Livros Horizonte, 1978; MARQUES, A. H. Oliveira - História de Portugal. v. III. Lisboa: Palas Editora, 1986; TELO, António José - Decadência e Queda da I. ${ }^{a}$ República Portuguesa. V.1 e 2. Lisboa: A Regra do Jogo, 1980; VALENTE, Vasco Pulido - O Poder e o Povo. Lisboa: D. Quixote, 1974) até nas análises mais actuais (ver, entre outros, ROSAS, Fernando - Pensamento e Acção Política. Portugal Século Xx (1890-1976). Ensaio Histórico. Lisboa: Editorial Notícias, 2003; TEIXEIRA, Nuno Severiano; PINTO, Antonio Costa (coord.) - A Primeira República Portuguesa. Entre o liberalismo e o autoritarismo. Lisboa: Ed. Colibri/ Instituto de História Contemporânea da Faculdade de Ciências Sociais e Humanas da Universidade Nova de Lisboa, 2000).

${ }^{472}$ Sobre o tema ver, entre outros, TORGAL, Luís Reis - "Sob o signo da 'reconstrução nacional". In Catroga, F.; TORGAL, Luís Reis; MENDES, José Maria Amado - História da História em Portugal. Lisboa: Circulo dos Leitores, 1996. 
"Não pertencemos ao número dos que pensam serpossivel o regresso, puro e simples, aos métodos e costumes políticos que antecederam o 28 de Maio. Fomos nós que lançamos a fórmula, hoje tanto em voga: 'nem o que está, nem o que estava!' O que está é criminoso, atroz; mas o que estava era insuficiente ${ }^{y_{7} 7_{3}}$.

No entanto, as dissidências políticas perduram entre os oposicionistas; as colaborações entre as diversas facções entre os exilados são um fruto momentâneo do ódio ao regime ditatorial e da defesa dos ideais republicanos. A questão do nacionalismo, tão presente na ideologia republicana e entre os seus opositores, é o grande traço de pertença dos exilados, que, em seu nome, combatem o regime ditatorial.

“[...] Bem, parece certo que não nasci para político e também presumo que em todos os cargos que exerci uma e única coisa fui sempre: português e nada mais" ${ }^{\prime \prime 74}$.

São estes os "baluartes" de uma "missão", orientada para a defesa de um "povo", com uma, ainda restrita, participação enquanto actor da sua própria história ${ }^{475}$.

O objectivo do presente artigo é analisar como um sector especifico da oposição, reunido em torno de Jaime de Morais, Alberto Moura Pinto e Jaime Cortesão e conhecido pelo epíteto de Budas ${ }^{476}$, considera e reelabora os postulados do republicanismo e como procura, através de planos de acção para o retorno da democracia em Portugal, reorientar os rumos da República.

${ }^{473}$ SANTOS, José Domingos dos - "Explicação Necessária". A Verdade, Paris, 26 de Novembro de 1938 , p. 1.

${ }^{474}$ MORAIS, Jaime - "Pelos domínios da política". In Notas biográficas manuscritas. Arquivo Jaime de Morais, p.1.

475 Sobre as considerações republicanas a respeito do conceito, ver, entre outros, RAMOS, Rui. -"Depoimento - o sentido histórico da I República Portuguesa”. In REIS, António (org.) - op. cit.; REIS, António - "Os valores republicanos de ontem e hoje". In Idem (org.) op. cit.

${ }^{476}$ A "alcunha" é dada pelos exilados reunidos em torno da figura de Ribeiro de Carvalho, já que este os acusa de não possuírem um maior "empenho revolucionário". Na verdade, a expressão aparece no livro de Ferro Alves, Os Budas e o contrabando de armas, editado em Portugal em 1934, sendo o seu autor reconhecidamente um espião salazarista no interior do grupo do reviralho. Sobre o tema ver: MARQUES, A. H. de Oliveira - A unidade da Oposição à Ditadura (1928-1931). Lisboa: Europa-América, 1973; MARQUES, A. H. Oliveira - A Liga de Paris e a ditadura militar (1927/1928). Lisboa: Europa-América, 1976; FARINHA, Luís - O Reviralbo. Revoltas Republicanas contra a ditadura e o Estado Novo: 1926-1940. Lisboa: Ed. Estampa, 1998. 
A sua trajectória política como oposicionistas é marcada pelo movimento de 3 de Fevereiro de 1927, quando Jaime de Morais ${ }^{477}$ e Jaime Cortesão ${ }^{478}$ participam activamente na tentativa de revolução e derrube do governo ditatorial. Exilados em Espanha, ali encontram Alberto Moura Pinto ${ }^{479}$ em 1931; juntos, passam a coordenar uma parte dos exilados em solo espanhol. Entre 1934 e 1939, articulam planos para o retorno da democracia a Portugal; o maior deles é o Plano Lusitânia, de carácter militar e político. Exilados no Brasil a partir da década de 40, continuam a pensar em formas de resistência ao regime e a elaborar planos para a futura reorganização do Estado Democrático em Portugal.

As marcas do republicanismo: a Maçonaria, o socialismo, o anarquismo e a revolução.

"Era republicano, acima de tudo, por me convencer que, só nesse regime seriam possíveis as reformas económicas e sociais que toda a minha vida ia considerar como essenciais" ${ }^{\prime \prime 80}$.

No pensamento republicano, vislumbram-se certos elementos que formam uma espécie de "marca" característica dos seus defensores e que é uma constante desse pensamento, anterior e posterior à ditadura militar ${ }^{481}$. Nomeadamente,

${ }^{477}$ Jaime Alberto de Castro Morais, médico da Marinha, ex-governador da Índia Portuguesa, natural de Chacim, Trás-os-Montes, é o responsável pelas operações militares do movimento de 1927 na cidade do Porto. Preso em 1928, consegue escapar da ilha de São Tomé, passando a viver em França e Espanha. Com o término da guerra civil espanhola e após uma fuga para o território francês e uma breve estada na Bélgica, retorna a Portugal, onde é preso e deportado para o Brasil. Falece naquele País em 20 de Dezembro de 1973.

${ }^{478}$ Jaime Cortesão, médico, combatente na Grande Guerra, está ligado ao grupo de intelectuais conhecido por Seara Nova, sendo director da Biblioteca Nacional quando participa na revolta de 3 de Fevereiro de 1927. O seu percurso é semelhante ao de Jaime de Morais, mas, ao contrário deste, obtém permissão para voltar a residir em Portugal, onde participa das eleições de 1958, falecendo em 1960.

479 Alberto Moura Pinto, advogado, deputado na constituinte de 1911, Ministro da Justiça no governo de Sidónio Pais, participa do movimento de oposição levado a cabo em 1928. Exilado nos Açores, consegue evadir-se em 1931, seguindo para a Espanha. Em Madrid, encontra Jaime de Morais e Cortesão, passando então a fazer o mesmo percurso de ambos. Com o final da guerra civil espanhola, parte para a França e daí directamente para o Brasil. Retorna a Portugal muito doente em 1958, onde falece dois anos mais tarde.

${ }^{480}$ MORAIS, Jaime - "Pelos domínios da política". In Notas biográficas manuscritas. Arquivo Jaime de Morais, p. (B).

${ }^{481}$ Sobre o tema ver, entre outros, CATROGA, Fernando - op. cit. 
a vinculação aos círculos maçónicos, a proximidade aos "ideais socializantes", a desconfiança relativamente aos anarquistas, aos comunistas e à imagem de um movimento popular sem controlo, estão presentes nas estratégias e técnicas de combate do "reviralho", como passou a ser conhecido o movimento.

Nascida no auge do liberalismo, a Maçonaria ganha força com a propagação dos ideais republicanos, contando, ainda no século XIX, com inúmeros adeptos entre os principais políticos do Partido Republicano. Com a República, a tradição maçónica, na política portuguesa, é reforçada com a presença de mações nos principais postos do novo regime ${ }^{482}$. António José de Almeida, Deputado, Ministro, Chefe de Governo e Presidente da República, torna-se mação em 1907, participando igualmente na Carbonária ${ }^{483}$.

Com o advento da ditadura militar e, posteriormente, com a institucionalização do Estado Novo, a Maçonaria é banida em Portugal e ilegalizada pelo regime. O vínculo, já existente entre o republicanismo e os princípios maçónicos, é reforçado pela oposição, na medida em que se torna uma dupla forma de identificação dos opositores. Na verdade, entre os que passam para a oposição a partir da implantação da ditadura militar, os mações já são maioritários. Afonso Costa, também Deputado, Ministro e Chefe de Governo, mação desde 1905, possui o nome simbólico de Platão. Bernardino Machado, com igual carreira política, alcança o título de Grão-mestre do Grande Oriente Lusitano, com o nome de Littré. José Domingos dos Santos, chefe do Partido Democrata, adopta o nome de Cimourdin, entrando nos quadros maçónicos em 1922. Brito Camacho, principal líder do Partido Unionista, está ligado à Loja Elias Garcia, de Lisboa, desde 1907. Ribeiro de Carvalho, Oficial do exército, Ministro da Guerra, tem o nome simbólico de Tônio. Sarmento de Beires é Bartolomeu Dias nos círculos maçónicos. Norton de Matos, Governador de Angola e candidato à presidência pela oposição, no após guerra, é também Grão-mestre da Maçonaria. Militar ao mesmo tempo que Ministro da República, Hélder Ribeiro é iniciado em 1911 com o nome simbólico de Febo Moniz. Para os que passam pelo exílio, a

${ }^{482}$ Sobre o tema, ver, entre outros, MARQUES, A. H. Oliveira - Dicionário da Maçonaria Portuguesa. Lisboa: Editorial Delta, 1986, v.1 e 2.

${ }^{483}$ A Carbonária é uma espécie de "força de choque", voltada para a intervenção directa na sociedade em defesa dos ideais de liberdade e igualdade. Sobre o tema ver, entre outros, MARQUES, A. H. Oliveira - Dicionário da Maçonaria Portuguesa, op. cit., v. I, p. 265, 266. 
Maçonaria, devido ao seu carácter internacionalista, acaba por ser um ponto de apoio e um auxílio na sobrevivência "física" dos exilados ${ }^{484}$.

No grupo dos "Budas", os principais nomes estão ligados aos círculos maçónicos. Jaime de Morais, militar, Governador de Angola e da Índia, é iniciado na Maçonaria em Luanda, em 1909, com o nome de Saint Just, usando-o em parte de sua correspondência política, no exílio. Alberto Moura Pinto entra para a Loja Tenacidade, em Águeda, no mesmo ano que Morais, adoptando o nome simbólico de Passos Manuel. Jaime Cortesão está vinculado à ordem com o nome de Guyau, entre 1911 e 1926, altura em que se afasta para, a ela, retornar, em 1934. Há menções a que eles teriam "fundado" uma loja maçónica portuguesa em Espanha, na dependência da Gran Lógia Reginal del Centro de España, quando do seu exílio naquele País ${ }^{485}$. Na correspondência de Jaime de Morais temos diversas referências aos contactos efectuados com a Maçonaria espanhola e a francesa. Um exemplo é quando, em Maio de 1939, exilado em Bruxelas após ter sido expulso da França, devido ao cumprimento de uma antiga ordem emitida em 1934, solicita, em diversas cartas enviadas à sua esposa, que procure saber das diligências realizadas junto aos círculos maçónicos franceses e das acções, por estes, concretizadas no sentido de permitir a sua reentrada no território francês para unir-se aos restantes exilados republicanos fixados em Paris ${ }^{486}$.

No entanto, quando seguem para o exílio no Brasil, os "Budas" não manterão assinaláveis contactos com a Maçonaria, ao contrário de alguns dos seus antigos companheiros da oposição. O antigo combatente republicano, Francisco Oliveira Pio, que se liga à Maçonaria ainda em território espanhol, cultiva a sua vinculação aos círculos maçónicos até morrer, em 1972, no Rio de Janeiro.

\footnotetext{
${ }^{484}$ O filho de Jaime de Morais, Oscar de Morais, é auxiliado pela Maçonaria na compra de livros e material escolar, quando reside em Lisboa e o seu pai já se encontra exilado. Ver carta de Oscar de Morais, datada de Lisboa de 15 de Dezembro de 1928, endereçada ao tesoureiro da Loja Elias Garcia, agradecendo a importância de quatrocentos escudos destinada a compra de livros. Anexo a Informação N. 859 - CI (2). 347/SR. ANTT

${ }^{485}$ Esta menção é feita por A. M. Gonçalves no site http://www.freemasons-freemasonry.com/arnaldoG.html, onde apresenta um historial da Maçonaria em Portugal. Ele afirma que a loja "República Portuguesa" foi fundada por Jaime de Morais e Moura Pinto. Na verdade, segundo documentação encontrada no Centro Documental de la Memória Histórica, em Salamanca, o organizador da loja é Filipe Mendes (PS. Madrid, 726). Em 1936 há uma carta sem o endereçado, datada de 4 de Janeiro, na qual Jaime de Morais assina com o seu nome simbólico maçónico, St. Just e comenta uma correspondência recebida acerca da possibilidade de apoio a uma revolta em Portugal. Arquivo de Jaime de Morais. Fundação Mário Soares.

${ }^{486}$ Ver correspondência entre Jaime de Morais e Alice de Morais datada de Bruxelas, dos dias 7, 12 e 21 de Maio de 1939. Arquivo de Jaime de Morais. Fundação Mário Soares.
} 
De igual forma, o anarquista e escritor Roberto das Neves, também exilado no Brasil, continua ligado aos grupos maçónicos daquele País. A aproximação de ambos ao General Humberto Delgado, quando do exílio deste último no Brasil, e a própria tradição de auxílio e combate dos mações contra o regime de Salazar, vão permitir a entrada do antigo candidato da oposição nos meios maçónicos e o pedido de ajuda financeira para os seus planos. Na verdade, Delgado, que até 1958 faz parte do regime e, como tal, nunca tivera nenhuma ligação com a Maçonaria, passa a ser tratado como irmão pelo Grande Oriente Espanhol, de São Paulo. Em 1961, em nome dos mações portugueses, um panfleto solicita aos "irmãos" brasileiros auxílio financeiro para a "batalha decisiva" a ser travada pelo General contra "o torvo e anacrónico regime que há tanto tempo avilta aos olhos do mundo progressista liberal e democrático a pátria de Camões". No pedido, a menção aos nomes de António José de Almeida e Afonso Costa, assim como a interdição do Grande Oriente Lusitano servem de argumento para o préstimo a ser dado ao militar e relembram a tradição maçónica entre os republicanos ${ }^{487}$.

Uma outra característica de um sector do movimento republicano é a sua vinculação com o pensamento "socialisante", ou mais ainda, com o conjunto de ideais políticos mais radicais que marcam o republicanismo português a partir das últimas décadas do século XIX. Anarquismo, socialismo, comunismo são doseados e adaptados ao conteúdo republicano de propostas políticas que marcam toda uma geração.

“[..] Não nos interessava Marx, Engels ou Proudhon, mas liamos com fanatismo Kropotkine, Bakunine, S. Faure e Jean Grave.

A mocidade de então era não somente republicana, mas estruturalmente individualista; e a filosofia política e económica do anarquismo dominava a sua massa.

A verdade, porém, é que não era um conformista perfeito dos credos em moda nesse tempo [...]

E, assim, longe de ser um republicano anarquisante, creio que melhor

\footnotetext{
${ }^{487}$ Fraternal apelo dos Maçons portugueses aos seus irmãos de todo o Brasil. Rio de Janeiro: 1961. Arquivo do Movimento Nacional Independente, mantido no Museu da República e da Resistência em Lisboa.
} 
defino a minha atitude dessa época dizendo que era mais um republicano socialisante, corrente e doutrina muito pouco em voga, nesse tempo, no País”88.

No caso da geração dos Budas e do seu círculo de apoiantes, eles herdam dos grandes debates de 1891 o gosto pela política e pela defesa pública dos seus ideais. A aproximação do "socialismo catedrático" é uma das principais referências na formação de um grupo de republicanos que vive os anos antecedentes à vitória da República ${ }^{489}$.

"Repare-se que os meus idolos doutrinários eram socialistas como Antero e Heliodoro Salgado, socialisantes como Oliveira Martins, historiadores como Martins Sarmento e Alberto Sampaio, e economistas como o meu professor Amandio Gonçalves (tão desconhecido e ignorado) e, acima de todos, Basílio Teles"'400.

A trajectória de vida de muitos deles serve de parâmetro para a compreensão de um sentido próprio de nacionalismo e cidadania, fruto de suas vivências nos primeiros anos do século xx. Para alguns deles, os anos vividos como estudantes contribuíram para a assimilação dos mecanismos de protesto e luta política. É o caso, por exemplo, de Ernesto Carneiro Franco e Jaime Cortesão activos participantes da Greve Académica de 1907. O primeiro é estudante de direito em Coimbra, e o segundo cursa medicina no Porto, sofrendo ambos as sanções impostas pela academia aos grevistas que protestam contra o arcaísmo das suas instituições ${ }^{491}$. Para outros, como Jaime de Morais, Oliveira Pio, César de Almeida ou João Sarmento Pimentel, a mais valia vem da experiência colonial e da defesa real da "integridade" de uma Nação, entendida a partir da inserção dos territórios coloniais. Neste mesmo sentido, a participação na Grande Guerra deixa as suas marcas profundas mais directas em combatentes como Jaime Cortesão, Nuno Cruz e Carneiro Franco ${ }^{492}$.

\footnotetext{
${ }^{488}$ MORAIS, Jaime - "Pelos domínios da política". In Notas biográficas manuscritas, p. (B). Arquivo Jaime de Morais, Fundação Mário Soares.

${ }^{489}$ Ver, entre outros, REIS, António - "Os valores republicanos de ontem e hoje". In Idem (org.) - op. cit.; CATROGA, F. - op. cit.

${ }^{490}$ MORAIS, Jaime - Notas biográficas manuscritas. Arquivo Jaime de Morais, Fundação Mário Soares.

${ }^{491}$ Ver CORTESÃO, J. - Memórias da Grande Guerra. Porto: Renascença Portuguesa, 1919.

${ }^{492}$ Sobre o tema ver, entre outros, PAULO, Heloísa - História. Novembro, 2006,
} 
Assim sendo, os "valores republicanos" do grupo são forjados no decorrer de um processo de amadurecimento político de uma geração, por vezes, reflectindo a própria trajectória do republicanismo e do regime republicano. Para eles, o Estado modelo tem por base a ideia de uma sociedade mais justa, definida pelos parâmetros de igualdade impostos por uma dada definição de cidadania. Neste sentido, a apologia da "República", é a defesa de uma "comunidade de cidadãos", sendo o Estado representante máximo dos valores nacionais. Do lado oposto, a Monarquia, é apresentada como o regime responsável pela crise económica, pela não cidadania, e pela submissão do País aos interesses estrangeiros, exemplificada pelo Ultimatum ${ }^{493}$.

De igual forma, é preciso ter em conta que tal noção de "igualdade" pode não ter por base uma assimilação pura e simples do socialismo, enquanto solução política universal ${ }^{494}$.

"[...] Como só o regime republicano me parecia possível, era republicano; como impressionado pela miséria da grey, era socialisante. Socialisante que não é rigorosamente a mesma coisa que socialista" ${ }^{\prime 49}$.

Assim sendo, em detrimento de quaisquer postulados políticos mais radicais está o ideal republicano, devendo o regime servir a sociedade que o legitima, assumindo uma postura "universal" no que respeita a sua actuação política. O servir a República é encarado como um acto de "altruísmo", já que significa a entrega total dos seus serviços em benefício dos cidadãos, independente dos credos políticos que possam ter:

"Escravos, agora, só os podia haver numa classe; os servidores, de todos os graus, da Nação, escravizados ao seu povo, escolbidos ou eleitos por este para cuidarem escrupulosamente do interesses da Grey"496.

\footnotetext{
${ }^{493}$ Sobre o tema ver, entre outros, REIS, António - "Os valores republicanos ontem e hoje". In Idem - op. cit., p.13.

${ }^{494}$ Sobre o tema ver, entre outros, REIS, António - "Os valores republicanos ontem e hoje". In op. cit., p.11 e seguintes.

${ }^{495}$ MORAIS, Jaime - "Pelos domínios da política". In Notas biográficas manuscritas. Arquivo Jaime de Morais, p. (B). Arquivo Jaime de Morais, Fundação Mário Soares.

${ }^{496}$ MORAIS, Jaime - Exame de Consciência. P.J. Arquivo Jaime de Morais, Fundação Mário Soares.
} 
Esta mesma razão serve de pano de fundo para a aproximação dos exilados aos mais diferentes grupos políticos no estrangeiro. Ou seja: em nome dos ideais republicanos e da defesa da causa são justificadas as alianças com os mais diferentes partidos, sejam eles ideologicamente próximos, como os socialistas, quer distantes, como os comunistas. É neste quadro que temos a aliança dos exilados em Espanha com a Esquerda Democrática de Manuel Azaña, irmanados no combate pelos ideais republicanos contra o franquismo ${ }^{497}$; a aproximação ao Partido Trabalhista Britânico, dada a afinidade das duas propostas ou, ainda, a actividade conjunta dos Budas e republicanos no Brasil e os membros fundadores do Partido Socialista, como Hermes de Lima, no findar da Segunda Guerra, unidos na condenação dos respectivos regimes ditatoriais, ambos denominados "Estado Novo"498.

A partir da década de 40, com o ressurgimento dos grupos socialistas portugueses no exílio, os Budas aceitam a aproximação que lhe é sugerida pelos próprios socialistas ${ }^{499}$. Nomes como os de Jaime Cortesão, Sarmento Pimentel, Hélder Ribeiro, aparecem vinculados à União Socialista, criada entre 1943 e 1945. Assim sendo, quando, em 1973, se constitui o Partido Socialista, foi destacada e sublinhada a presença de Sarmento Pimentel, apresentado com um verdadeiro "ícone" da resistência republicana, da qual os socialistas se vêem como herdeiros ${ }^{500}$.

As ligações entre os Budas e o movimento anarquista decorrem no mesmo sentido. Os contactos com os anarquistas acontecem em Portugal, Espanha e França. Figura de maior relevo é o anarquista Inocêncio Câmara Pires, que coordena um grupo de auxílio aos republicanos espanhóis, e, concomitantemente, aos portugueses ${ }^{501}$.

As relações com os comunistas são sempre mais conflituosas e vistas como fruto de um instável jogo político. Durante a guerra de Espanha, os Budas entram em conversações com elementos do Partido Comunista, nomeadamente,

${ }^{497}$ É notória a ligação dos Budas com o grupo de Azanã e de Indalecio Prieto, como podemos atestar por inúmeras citações nas correspondências de Moura Pinto, Cortesão e Jaime de Morais trocadas em solo espanhol e depois no exílio. Ver Arquivo Moura Pinto e Arquivo Jaime de Morais.

${ }^{498}$ Sobre o tema, ver PAULO, Heloisa - "O exílio português no Brasil: Os 'Budas' e a oposição antisalazarista”. In Portuguese Migration in Comparison: bistorical paterns and Transnational Communities. Portuguese Studies Review, Trent University, Peterborough, Ontario, Vol. 14, No. 2. Junho de 2009

${ }^{499}$ Sobre o tema ver, entre outros, MARTINS, Susana - Socialistas na Oposição ao Estado Novo. Lisboa: Casa das Letras, 2005.

\footnotetext{
${ }^{500}$ Idem.

${ }^{501}$ Ver Arquivo Moura Pinto.
} 
com o próprio Álvaro Cunhal. Mas a resistência a este relacionamento é bilateral. A descrição que Moura Pinto faz de uma conversa com um membro do Partido Comunista, aquando da Guerra de Espanha, deixa claro tal posicionamento.

“Quando estava no quarto apareceu-me o 'papagaio'. Disse-lhe coisas duras. Retribuiu-me com a linha do partido. Declarei-lhe então que nem o papa, se eu fosse católico, nem Carlos Marx, se eu fosse comunista, me imporiam nada que atraiçoasse o meu país e os meus camaradas" $" 502$.

Constitui uma excepção o laço estabelecido, nos anos sessenta, entre o Grémio Republicano de São Paulo, chefiado por Sarmento Pimentel, e o grupo vinculado ao jornal Portugal Democrático, cujos elementos são, maioritariamente, ligados ao Partido Comunista. Neste período, quando o republicanismo já não conta com uma boa parte dos seus militantes, os antigos opositores no Brasil buscam, na renovada militância comunista, uma base de apoio para dar continuidade ao seu trabalho de combate ao salazarismo ${ }^{503}$.

Como pano de fundo da possibilidade de relacionamento com socialistas, comunistas ou anarquistas está a concepção de "revolução". Do mesmo modo que alguns historiadores consideram a implantação da República como um movimento revolucionário, pelas profundas mudanças que introduz na sociedade ${ }^{504}$, vemos idêntico raciocínio nos mais variados matizes do discurso oposicionista republicano. Para eles, o conceito de "revolução" é justificado pelo facto de se ter pretendido uma mudança total que, embora não alcançada, caberia à oposição levar adiante, uma vez victoriosa:

"[...]Revolução é acabar com a arraigada ignorância, infundindo cultura à nossa grei; é abrir a brecha profunda no sistema das oligarquias, realizando

${ }^{502}$ PINTO, Alberto Moura - Anotações manuscritas em forma de diário tomadas entre Novembro de 1936 e o de 1937. p. 108. Arquivo Moura Pinto.

${ }^{503}$ Sobre o tema, ver, entre outros, PAULO, Heloisa - "Aqui também é Portugal!". A colónia portuguesa do Brasil e o salazarismo. Coimbra: Quarteto, 2000 e SILVA, Douglas Mansur - A oposição ao Estado Novo no exílio brasileiro: 1956-1974. Lisboa: Imprensa de Ciências Sociais, ICSUL, 2006.

504 Sobre o tema, ver, entre outros, RAMOS, Rui - "A Revolução Republicana Portuguesa de 1910-1911: uma interpretação”. In MARTINS, Fernando; OLIVEIRA, Pedro Aires - As Revoluções Contemporâneas. Lisboa: Colibri, 2005. 
a democratização do nosso crédito, promovendo no povo a instrução técnica e a acessão do pobre a propriedade; é dar combate a miséria pública, fomentando o progresso na agricultura, e aproveitando a água dos nossos rios para regar terras que nos dêem pão, para fornecer à indústria energia eléctrica; é salvar a raça que vai morrendo e que chegou a extremos inconcebiveis de miséria e de abjecção; enfim, é educar o povo na autonomia e no domínio de si mesmo, criando no país as condições de uma civilização espiritual"’05.

Frente ao papel desempenhado pelos militares no 28 de Maio e à sua importância no seio da oposição entre os republicanos ${ }^{506}$, a problemática da "revolução" é discutida em ligação à questão do papel desempenhado pelo exército nos grandes movimentos de mudança em Portugal. Assim, e pretendendo distinguir os militares de 1926 daqueles que lutam na oposição, o exército passa a ser "dividido" em duas categorias: os que agem em prol da sociedade, e os que fazem da carreira militar um ofício como outro qualquer. Aos primeiros, a que muitos dos republicanos se vinculavam, cabia a designação de "revolucionários":

"[...]Dizia-se que o nosso intuito era ofender firmemente o exército, opondo-lhe massas de civis, num gesto de deslealdade. Posso afirmar que jamais tal pensamento tivemos. [...]

Tínhamos uma ideia talvez bizarra, que Nuno resumia assim: temos dois exércitos, o que se destina a guerra e o que serve para procissões, ele pertencia ao primeiro. Mas essa ideia mesmo denunciava nosso sentimento militar ${ }^{507}$

Por fim, todos os pressupostos são postos à prova quando revista a conduta do anterior período republicano. A crítica ao antigo Estado e aos políticos da República é o ponto de partida para a fundamentação do argumento dos exilados do retorno

505 SÉRGIO, António - "A Revolução". A Revolta. Lisboa, 23-30 de Abril de 1927, p. 3.

506 Sobre o tema, ver entre outros, FERREIRA, José Medeiros - O Comportamento Político dos Militares. Forças Armadas e regimes políticos em Portugal no séc. xx. Lisboa: Ed. Estampa, 1992, ou ainda, CARRILHO, Maria - Forças Armadas e Mudança Política em Portugal no Séc. xx. Lisboa: Imprensa Nacional-casa da Moeda, 1985.

${ }^{507}$ MORAIS, Jaime - "Últimas Fantasias". In Notas biográficas manuscritas. P. 9. Arquivo Jaime de Morais, Fundação Mário Soares. O "Nuno" referido é Nuno Cerqueira Machado Cruz, companheiro dos Budas desde de 1927 e que falece em Madrid em 1934. 
à normalidade constitucional. Assim sendo, é preciso rever as antigas fórmulas republicanas para que não se repitam os erros do passado. A condenação da ditadura é sempre acompanhada do repensar da prática republicana anterior a 1926:

"Queremos o regresso à Constituição. Queremos a Democracia. Queremos o Parlamentarismo. Mas queremo-los modificados, aperfeiçoados, renovados de forma que possam satisfazer às enormes necessidades da bora presente, e tornem impossível a repetição de governos ditatoriais os quais, a experiência amargamente tem demonstrado, só tem contribuído para a ruína do País e servido jesuiticamente as aspirações e intentonas monárquicas em Portugal"\$08.

Neste sentido, uma das razões fundamentais do fracasso do republicanismo está na sua própria organização enquanto Estado. A disputa partidária do poder em detrimento da defesa dos interesses sociais é vista como a causa, não só do regime, mas também do possível fracasso do movimento de oposição à ditadura:

"Mais que tudo, Senhor Presidente, eu ambiciono colaborar na restauração da República, e nunca em revoltas deste grupo ou daquela facção, pois está provado que só servem para manter no Governo os nossos inimigos e consolidar a ditadura.

Chegou a hora de pôr ponto na indisciplina republicana que tantas desgraças e sofrimentos têm causado. Até aqui só organizamos as nossas derrotas, sendo que da de 1927 me cabem tremendas responsabilidades"509.

A principal questão a resolver passa a ser a da reestruturação do sistema representativo e a do Estado Republicano. A ineficácia da máquina parlamentar e a sua inoperância em termos de superação das divergências políticas em prol de planos comuns de cunho social são os principais alvos do discurso oposicionista. A crítica à dispersão dos grupos políticos em debates sobre a forma de actuar contra a ditadura recupera o passado dos grandes entraves surgidos

\footnotetext{
508 "A Nossa Posição". A Revolta. Lisboa, 23-30 de Abril de 1927, p. 1.

${ }^{509}$ Carta de João Sarmento Pimentel a Bernardino Machado, datada de Bayona, 12 de Setembro de 1931, Arquivo Bernardino Machado no Museu Bernardino Machado, Vila Nova de Famalicão.
} 
na articulação de propostas no Parlamento. Daí, o apelo constante aos aliados para que actuem como "parceiros", ultrapassando os interesses partidários e não permitindo o retorno dos antigos vícios da velha República:

"Queremos firmemente destruir os erros cometidos desde Maio; mas não queremos regressar pura e simplesmente à situação que lhe foi imediatamente anterior [...]

Queremos fazer regressar o País a normalidade constitucional e ao uso de todas as suas liberdades públicas; mas temos uma aspiração maior ainda; queremos que a paz se estabeleça entre republicanos, que as paixões se apaguem e que, por mais distantes que sejam os ideais que dividem os homens do Regime eles não possam ir além de conflitos de ideias e não de pessoas" ${ }^{\prime 10}$.

A revisão dos pressupostos republicanos, pelos opositores ao novo regime, não descaracteriza o seu republicanismo, nem o uso da República como símbolo de combate contra a ditadura em Portugal. Mas, uma vez estabelecidas as razões da luta, é necessário traçar os rumos do novo Estado. Neste sentido, planear novas instituições que produzam as mudanças necessárias, torna-se imprescindível.

\section{A reinvenção da República pela oposição: os Planos de Reestruturação do Estado}

\section{Republicano.}

"Se este raciocínio é justo, o problema nacional que se nos põe na hora do desmoronamento do fascismo fradesco em que vivemos consiste em procurarmos a melhor e mais rápida maneira de construirmos uma economia nova que permite ao português o bem estar social a quem legitimo direito e um nível de vida equivalente ao dos povos que são seus parentes mais próximos e com os quais tem que viver em fraternidade"s11.

\footnotetext{
${ }^{510}$ Cópia de carta não datada endereçada aos dirigentes vogais da Directoria do P.R.P., António Maria da Silva e Daniel Rodrigues por Jaime de Morais. Arquivo Jaime de Morais, Fundação Mário Soares.

${ }^{511}$ Memorando acerca do Problema Nacional. P. (a). Arquivo Jaime de Morais, Fundação Mário Soares.
} 
A derrota do movimento iniciado a 3 Fevereiro de 1927, na cidade do Porto e os fracassos de 1928 e 1931, levam o grupo de republicanos, reunidos em torno dos "Budas", a repensar soluções e estratégias de combate para a restauração do Estado Democrático em Portugal.

No Arquivo de Jaime de Morais encontram-se apontamentos a respeito de dois planos de acção para o futuro governo republicano. O primeiro remonta ao período de exílio em Espanha; é uma espécie de historial do que foi pensado e do que seria proposto pelos "Budas", caso tivessem obtido o sucesso na sua luta contra o regime. O segundo é escrito no final da Segunda Guerra, quando o fim do conflito é visto pelos opositores como uma possibilidade de derrube da ditadura salazarista ${ }^{512}$.

No primeiro desses "planos", apontado como tendo sido pensado entre 1930 e 1934, é dado destaque à actuação e intervenção do Estado em diversos sectores da economia, nomeadamente, nas finanças, na energia, nos transportes e na agricultura. A nacionalização é vista como necessária nos processos de mudança a ser levados adiante e é sempre referida como essencial para o desenvolvimento da sociedade, desde que acompanhada de contrapartidas aos antigos proprietários, custeadas pelo Estado:

"Fomos sempre hostis a expropriação pura e simples. Íamos fazer uma revolução, mas não usamos de processos clássicos da anarquia revolucionária.

Também não vamos fazer socialismo puro e menos comunismo clássico.

Nacionalizar tem o sentido de resgatar, comprar.

Claro que a preço justo, mas jamais excessivo. E pago não a dinheiro, mas em títulos de obrigações de um novo tipo de DIVIDA PÚBLICA, garantida pelos próprios bens que vamos nacionalizar's13.

Esta medida de intervenção estatal deve abranger as mais diversas actividades, como os caminhos-de-ferro e a produção de energia. O papel do Estado é encarado a partir dos parâmetros do Estado Social, agindo este de forma

\footnotetext{
512 O segundo plano provavelmente é escrito em 1945, quando a oposição é reorganizada no Brasil.

${ }^{513}$ Anotações dactilografas de Jaime de Morais sobre o Plano Lusitânia. P. 4. Arquivo Jaime de Morais, Fundação Mário Soares
} 
dupla, ou seja, como financiador e administrador e com objectivos mais centrados na reorganização da economia do que no lucro com os investimentos feitos:

"Que o Estado perca com a exploração de centrais eléctricas, caminhos de ferro, mesmo bancos de crédito, nada importa. O fim é económico sempre e nunca financeiro. Note-se, de resto, que com uma administração hábil, dificilmente se perde [...]"sit.

A administração interna do território é orientada para facilitar a tomada das medidas a serem implementadas pelo novo Estado. Neste ponto, como em alguns outros, o sentido prático sobrepõe-se às questões de ordem política, sendo que a questão da divisão interna do território é preterida em detrimento da articulação dos poderes locais:

"Não nos interessava, então (e presumo que menos hoje) a ressurreição das províncias e menos a defesa dos distritos que nunca foram uma realidade no nosso país.

A Constituinte resolveria o caso como quisessem. O que nos interessava era a organização administrativa no que aos fins do programa importa.

Suponhamos que havia que estudar escrupulosamente o país e nele talhar pequenas áreas que somariam um número modesto e variável de concelhos e em cuja sede concentrávamos tudo o que se refere a assistência médica, técnica, agrícola e pecuária, ensino e justiça.

Retalhos que as vias de comunicação permitissem, dentro de distâncias máximas a fixar e que podiam ser variáveis"s15.

Na verdade, este "plano" acompanha uma boa parte do raciocínio que um sector dos republicanos desenvolve acerca das mudanças necessárias ao País, a partir da falência dos modelos liberais de Estado ${ }^{516}$. Algumas das propostas

\footnotetext{
${ }^{514}$ Anotações dactilografas de Jaime de Morais sobre o Plano Lusitânia. P. 4. Arquivo Jaime de Morais, Fundação Mário Soares.

515 Anotações dactilografas de Jaime de Morais sobre o Plano Lusitânia. P. 4. Arquivo Jaime de Morais, Fundação Mário Soares.

${ }^{516}$ Sobre o tema, ver, entre outros, HOMEM, Amadeu Carvalho - "Constituição de 1911: Programa
} 
retomam o conteúdo de outras que lhes são anteriores, como a do próprio António Sérgio, já citada. O relevo dado aos problemas educacionais e à formação especializada, recupera o antigo discurso republicano sobre a estruturação da cidadania através da educação; mas oferece uma nova visão sobre o processo, no qual a construção da cidadania passa pela valorização da formação e do trabalho. Neste sentido, a captação de técnicos e especialistas deve ser regida pelo seu desempenho, desprezando o compadrio político, mas favorecendo a possibilidade de um novo vínculo entre Estado e cidadão:

"Nisto não há que hesitar e jamais pode haver 'política'.

Há técnicos de caminhos de ferro, bancários, de electricidade, de transportes marítimos perfeitamente capazes e hábeis, mas que são nossos adversários políticos, ou, pelo menos, não mostram entusiasmo pelo nosso credo político?

Não há que hesitar: aceitam-se. Vamos mais longe: impõe-se-lhe a obrigação de cooperar.

Ganham muito? Pois ganharão muito. Tanto como hoje, mais do que hoje, os que preciso for. Mas, serão informados de que tem liberdade de acção, mas que por ela serão responsáveis. E essa responsabilidade será rigorosamente tomada sempre que for preciso.

Mais: escolhe-se uma elite de gente nova, capaz mas inexperiente, que ao lado desses técnicos e administradores se coloca, como seus assessores.

Na realidade, são alunos. Em breve, neles terei um corpo de elite para o desempenho de funções mais delicadas desta máquina.

Elite de gente nossa, fanaticamente presa à nossa doutrina. Muito bem paga, entenda-se e acarinhada. Deles dependerá o nosso futuro"s17.

A mesma ideia é retomada quando o "Plano" aborda a questão da "assistência social" e da instrução, consideradas fundamentais para complementar as medidas a nível económico:

de uma Burguesia Livre Pensadora". In História, n. ${ }^{\circ} 43$ (Março 2002), pp. 32-37; RAMOS, Rui - "Foi a Primeira República um regime liberal? Para uma caracterização política do regime republicano português entre 1910 e 1926". In BAIÔA, Manuel - op. cit., pp. 185-246.

${ }^{517}$ Anotações dactilografas de Jaime de Morais sobre o Plano Lusitânia. P. 4. Arquivo Jaime de Morais, Fundação Mário Soares. 
"O trabalhador português tem que atingir o mesmo nivel de vida, em todos os terrenos, do trabalhador mais favorecido da Europa.

Para este fim, tudo sacrificamos. Para ele, daríamos um esforço gigantesco. As vantagens a obter compensam tudo, fartamente.

Tem que acabar a miséria e a tristeza da nossa vida nacional.

Sem tiros, nem procissões com consignas e estandartes.

Quando a massa atinja a dignidade de viver que lhe queremos dar, livre é de escolber o caminho que quiser"s18.

A visão republicana do papel do político, como uma espécie de "mentor" da sociedade ${ }^{519}$, na qual a "cidadania" é forjada a partir de determinados factores que são "oferecidos" pelo Estado ao "povo", está, novamente, presente neste tipo de formulação. É necessário acabar com a miséria para que a população possa ter condições de escolha e não tenha que se "sujeitar" às barganhas políticas, quer sejam elas impostas interna ou externamente:

"Procuraremos conquistar uma plataforma de partida, de largada: já não nos cumpre fixar o novo rumo ulterior. O nosso fim é que, na hora da decisão, o português esteja numa posição de igualdade com todos os demais. O que pretendemos é que ele não seja povo escravo de povos capitalistas, fascistas ou comunistas. [...] A verdade é que nada se pode construir sem ser por cima de uma suficiência económica do cidadão,"520.

O resumo das propostas, formuladas nos anos 30, é acompanhado de explicações do seu fracasso posterior; nelas, não são questionadas as condições reais de aplicabilidade do plano, mas o seu impacto político sobre os demais grupos, retomando a tónica inicial da necessidade constante de uma união das oposições:

${ }^{518}$ Anotações dactilografas de Jaime de Morais sobre o Plano Lusitânia. P. 6. Arquivo Jaime de Morais, Fundação Mário Soares

${ }^{519}$ Sobre o tema, ver, entre outros, CATROGA, Fernando - op. cit. e HOMEM, Amadeu Carvalho, op. cit.

${ }^{520}$ Anotações dactilografas de Jaime de Morais sobre o Plano Lusitânia. P. 9. Arquivo Jaime de Morais, Fundação Mário Soares. 
"Porque fracassamos?

Em primeiro lugar porque sempre fugimos de publicar o nosso programa.

Porque?

A vitória estava ainda incerta e temíamos das duas uma: ou ele era atacado pelos nossos adversários e era-nos impossível defendê-lo com armas suficientes, que já não digo iguais; ou acabava por ser ele adoptado na parte que lhes interessava, e, como o seu objectivo era outro, fracassava fatalmente e com isto fracassava a nossa ideia.

Depois, porque o seu conhecimento ia dividir fortemente o nosso campo"s21.

No final da Segunda Grande Guerra, temos um novo "plano" de reformas políticas, apresentado como uma espécie de "memorando" dos Budas e do seu grupo para a oposição em geral. O discurso é muito semelhante ao anterior, ainda que muito mais veemente e directo. Apesar disto, recoloca os antigos pressupostos, considerados fundamentais no primeiro projecto, como, por exemplo, a necessidade de uma união de todos os segmentos políticos da oposição:

"Restabelecido, em Portugal, um regime democrático, não é um problema político que os seus homens de estado tem de resolver. Por algum tempo, e este não excessivamente curto, pouco devem interessar os portugueses as lutas de ideologias. Precisam, sim, de ser livres, mas, na realidade, a pugna por um triunfo do socialismo, do comunismo ou do sindicalismo não tem justificação plausível no momento"s22.

A ideia da via económica como o elemento essencial na reestruturação do Estado Democrático é explicitada, sendo o discurso sobre este tema muito mais radical que o anterior. Para além do problema da nacionalização, a resolução dos problemas da reorganização da economia assumem os modelos dos Estados socialistas, sendo sempre salvaguardada a diferença entre o "ser socialista" e o "socializante":

${ }^{521}$ Anotações dactilografas de Jaime de Morais sobre o Plano Lusitânia. P. 9. Arquivo Jaime de Morais, Fundação Mário Soares. A "dissidência”, segundo Morais, teria partido do sector comunista, já que o plano republicano estaria compostos de medidas que retirariam dos comunistas os seus principais objectivos.

${ }^{522}$ Memorando acerca do Problema Nacional. P. (a). Arquivo Jaime de Morais, Fundação Mário Soares 
"Quero dizer: na primeira fase socializamos muito, mas no objectivo não de organizar um estado socialista, mas sim o de se permitir a nação escolher, quando reconstruída, o seu caminho, admitindo-se mesmo a bipótese de um regresso a um regime de larga liberdades económicas, mas nunca por forma a retirar-se das mãos do Estado o manejo das válvulas de segurança que com tamanho esforço vai construir"s23.

Neste sentido, o conceito de "revolução" é retomado de uma forma mais incisiva daquela usada nos anos 30, nos meios republicanos. A ideia de "revolução económica nacional" está presente no discurso, que justifica o emprego do termo no âmbito da sua época:

'Que não nos aterre muito a palavra 'revolução', pois de há muito, mesmo nos meios mais reaccionários tomou já foros de cidade.

E devemos mesmo preferi-la à de renovação, reconstrução, ou re-estruturação, pois ela melhor é compreendida pelas massas que, acima de tudo, há que interessar na cruzada"s24.

De igual forma, os exemplos tomados da União Soviética são mencionados, mas evitando os possíveis arrufos políticos, são "adaptados" sempre á realidade nacional:

"Não importa copiarmos o Kolbvoz russo, pois isso seria politicamente perigoso, mas podemos organizar um erzatz, modelo lusitano, donde possamos retirar as mesmas vantagens ${ }^{\prime 525}$.

O uso de um discurso mais incisivo está inserido no seu contexto de época, onde os avanços dos aliados na Europa contavam com a participação expressiva das tropas soviéticas. Este mesmo quadro serve de pano de fundo às especulações

\footnotetext{
523 Ibidem.

${ }^{524}$ Ibidem. P. (b). Arquivo Jaime de Morais, Fundação Mário Soares.

${ }^{525}$ Memorando acerca do Problema Nacional. P. (6). Arquivo Jaime de Morais, Fundação Mário
} Soares. 
acerca da posição de Portugal na nova ordem que se esboça para a Europa, uma vez restaurada a ordem democrática:

"Integre-se Portugal num bloco oeste-europeu, onde vigore um regime de democracia social adiantado, ou num bloco americano, vivendo uma democracia liberal e individualista, ou num bloco europeu comunista ou comunisante - o seu povo, no seu nível de vida actual e a nação com a sua presente economia, na sociedade a que vier a pertencer, será sempre um servo, ou melhor, explorado. Que o possa ser em maior ou menor escala, importa pouco, pois o que sumamente interessa é que possa ser igual aos demais membros da família a que pertencer's26.

A vitória aliada não significa a tão esperada queda do regime salazarista, nem tampouco a possibilidade de qualquer tipo de avanço da oposição portuguesa no sentido do restabelecimento das liberdades democráticas em Portugal. Os exilados republicanos, quer no Brasil, nos Estados Unidos, na Venezuela ou em França, continuam o combate ao Estado Salazarista. A grande maioria deles, como Jaime de Morais, Moura Pinto, Jaime Cortesão, Oliveira Pio, não sobrevive para ver o retorno do País à normalidade democrática. Um dos poucos "resistentes" vivo, por ocasião do 25 de Abril, é João Sarmento Pimentel, que congrega as mais diferentes matizes da oposição no Centro Republicano Português de São Paulo, onde, mais uma vez, a República é o grande símbolo da resistência ao fascismo em Portugal.

${ }^{526}$ Ibidem. P. (a). Arquivo Jaime de Morais, Fundação Mário Soares. 